\title{
PARASITIC NEMATODES OF REPTILES (LIZARDS AND SNAKES) IN THE MONTE DESERT OF ARGENTINA
}

\author{
Gabriel Natalio Castillo ${ }^{1,2}$, Juan Carlos Acosta ${ }^{1,2}$ \\ Cynthia Jessica González-Rivas ${ }^{1}$, Geraldine Ramallo ${ }^{3}$ \\ ${ }^{1}$ Facultad de Ciencias Exactas, Físicas y Naturales, Universidad Nacional de San Juan \\ Av. Ignacio de la Roza 590, 5402, San Juan, Argentina \\ E-mails: nataliocastillo@gmail.com; https://orcid.org/0000-0003-1519-9457 \\ jcacostasanjuan@gmail.com; https://orcid.org/0000-0003-3539-8568 \\ cynthiajesica.gr@gmail.com \\ ${ }^{2}$ Gabinete de Investigación DIBIOVA (Diversidad y Biología de Vertebrados del Árido) \\ Universidad Nacional de San Juan. Av. Ignacio de la Roza 590, 5402, San Juan, Argentina \\ ${ }^{3}$ Instituto de Invertebrados. Fundación Miguel Lillo, San Miguel de Tucumán, Argentina \\ E-mail: gramallo@lillo.org.ar; https://orcid.org/0000-0002-6953-4743
}

Nematodes are little known in the Argentine herpetofauna. In order to increase and contribute to the knowledge of parasitism in reptiles, we studied nematodes found in three species of lizards (Aurivela longicauda, Liolaemus darwinii, and L. riojanus) and one species of snake (Philodryas trilineata) from the Monte desert of center-west Argentina. We registered generalist nematodes commonly found in reptiles, belonging to three taxa: Physaloptera sp. (larvae), Physaloptera retusa (adults) (Physalopteridae) and Parapharyngodon riojensis (Pharyngodonidae) (adults). Liolaemus darwinii had the lowest prevalence of Physaloptera sp. (larvae) $(30 \%)$ and a mean intensity of $1.3 \pm 0.4(1-2)$. The lizard $A$. longicauda had the highest parasitic diversity ( 2 taxa) with prevalence $(50 \%)$ and mean intensity (4 \pm 3.5$)$ of Physaloptera retusa (adults),

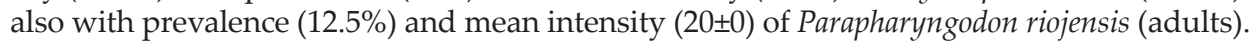
Due to the low number of studied specimens, precise conclusions cannot be drawn for $L i$ olaemus riojanus $(\mathrm{n}=2)$ and $P$. trilineata $(\mathrm{n}=1)$. However, because the hosts were previously fixed, the results probably may do not represent real infection patterns.The four reptile species correspond to new host records from Argentina, and the information provided contributes to the knowledge of endoparasitism in reptiles of the Argentine Monte region.

Key words: parasitic nematodes, Parapharyngodon riojensis, Physaloptera retusa, Liolaemus, Aurivela, Philodryas, lizard, snake.

\section{INTRODUCTION}

Until 2004, information about endoparasite metazoans in Argentine lizards has been scarce (Goldberg et al. 2004). However, in the last years an increase in the knowledge about parasitism in reptile species has occurred. Such increases are mainly due to the contributions about nematodes in reptiles from Monte and Puna regions in Argentina (CAstillo et al. 2019a, b).

Although the Monte region covers an extensive area of Argentina (KARLIN et al. 2017), to date, parasites were only studied in a reduced number of 
reptile species; namely Salvator rufescens, Teius teyou (Teiidae), Homonota underwoodi (Phyllodactylidae) and Liolaemus olongasta (Liolaemidae) (CAstillo et al. 2019a, b).

Information about parasite biodiversity is essential, since parasites may play an important role in the ecology of reptiles. It is well-known in the literature that nematode communities are influenced by attributes of the host, such as phylogenetic historical factors (BRITo et al. 2014), diet (Ribas et al. 1995, O'Grady \& Dearing 2006, Pereira et al. 2012, 2014, Brito et al. 2014), foraging strategy (active and passive search) (Aно 1990, BRITo et al. 2014), microhabitat use (BRITO et al. 2014); reproduction (BRITO et al. 2014, GALDINo et al. 2014), sexes (Ribas et al. 1995, Vrcibradic et al. 1999, Brito et al. 2014), age (Pereira et al. 2012), body size (VAN Sluy et al. 1994, Ribas et al. 1995, VRCibradic et al. 1999, Anjos et al. 2005, 2012, Pereira et al. 2012) and environmental characteristics such as humidity or type of habitat (CAstillo et al. 2018).

In order to contribute to the knowledge of the parasitic nematodes of reptiles in the Monte region of Argentina, we analyzed the gastrointestinal content of four species of reptiles (A. longicauda, L. darwinii, L. riojanus and $P$. trilineata) captured in the previously mentioned area.

\section{MATERIAL AND METHODS}

The Monte phytogeographic region encompasses large arid areas, with an average annual precipitation lower than $100 \mathrm{~mm} /$ year, including absence of annual precipitation. Xerophyte plants adapted to dry and warm weather predominate. The sector is characterized by scrublands dominated by Zigophylaceae, Malpigiaceae and Fabaceae (CABrera 1976, Márquez et al. 2016).

Sampling was carried out in different periods and sectors of the Monte desert of San Juan province, Argentina (Figs 1 \& 2). During December 2017 and January 2018, pitfall traps and manual capture were used, and the following species were collected and examined: the lizards Liolaemus darwinii (Liolaemidae), Liolaemus riojanus (Liolaemidae) (Liolaemidae) and Aurivela longicauda (Teiidae), and the snake Philodryas trilineata (Dipsadidae) (Table 1). Two lizards and the snake species (i.e., L. darwinii, A. longicauda and Philodryas trilineata) have wide distribution in the Monte region and or other provinces from Argentina, and are not under any conservation threat (GIRAudo et al. 2012). While L. riojanus is categorized as vulnerable and has more restricted distribution (ABDALA et al. 2012).

All host specimens were deposited in the Herpetological Collection, Biology Department, School of Exact, Physical, and Natural Sciences, National University of San Juan (Philodryas trilineata: UNSJ 4010; L. riojanus: UNSJ 4011, 4012; A. longicauda: UNSJ 40134032; L. darwinii: 4033-4052).

Captured specimens were euthanized with an intraperitoneal administration of sodium thiopental, fixed in $10 \%$ formalin, and preserved in $70 \%$ ethanol. In the laboratory, the dissection and analysis of the digestive tract was carried out. The lizards were dissected through a ventral incision from mouth to anus, digestive tract was extracted and revised using a binocular stereomicroscope. Nematodes found were conserved in $70 \%$ ethanol. 
Table 1. Reptiles studied from the Monte desert, central-western Argentina.

\begin{tabular}{lccc}
\hline Host & Specimens & Locality & Geographical coordinates \\
\hline $\begin{array}{l}\text { Teiidae } \\
\text { Aurivela longicauda }\end{array}$ & $\hat{\jmath}=4 ; \uparrow=4$ & Encón, Dept. 25 de Mayo & $32.182839^{\circ} \mathrm{S}, 67.824371^{\circ} \mathrm{W}$ \\
$\begin{array}{l}\text { Liolaemidae } \\
\text { Liolaemus darwinii }\end{array}$ & $\hat{O}=16 ; \uparrow=24$ & Encón, Dept. 25 de Mayo & $32.182839^{\circ} \mathrm{S}, 67.824371^{\circ} \mathrm{W}$ \\
$\begin{array}{l}\text { Liolaemus riojanus } \\
\text { Dipsadidae }\end{array}$ & $\uparrow=2$ & Encón, Dept. 25 de Mayo & $32.182839^{\circ} \mathrm{S}, 67.824371^{\circ} \mathrm{W}$ \\
Philodryas trilineata & juvenile & Urban Sector, Dept. Rivadavia & $31^{\circ} 31^{\prime} 00^{\prime \prime} \mathrm{S}, 68^{\circ} 36^{\prime} 00^{\prime \prime} \mathrm{W}$ \\
\hline
\end{tabular}

For identifictation of parasites, specimens were cleared in lactophenol, observed using an Arcano light microscope, following specific literature (Anderson et al. 2009, Pereira et al. 2012, 2014). Prevalence, mean intensity and mean abundance of parasites were according to Bush et al. (1997). All nematodes were deposited in the Colección Parasitológica, Department of Biology, Fac. of Exact, Physical and Natural Sciences, National University of San Juan, Argentina, (Physaloptera retusa (Adults): UNSJPar260; Physaloptera sp. (Larvae): UNSJPar 261, 262, 263; Parapharyngodon riojensis: UNSJPar 264).
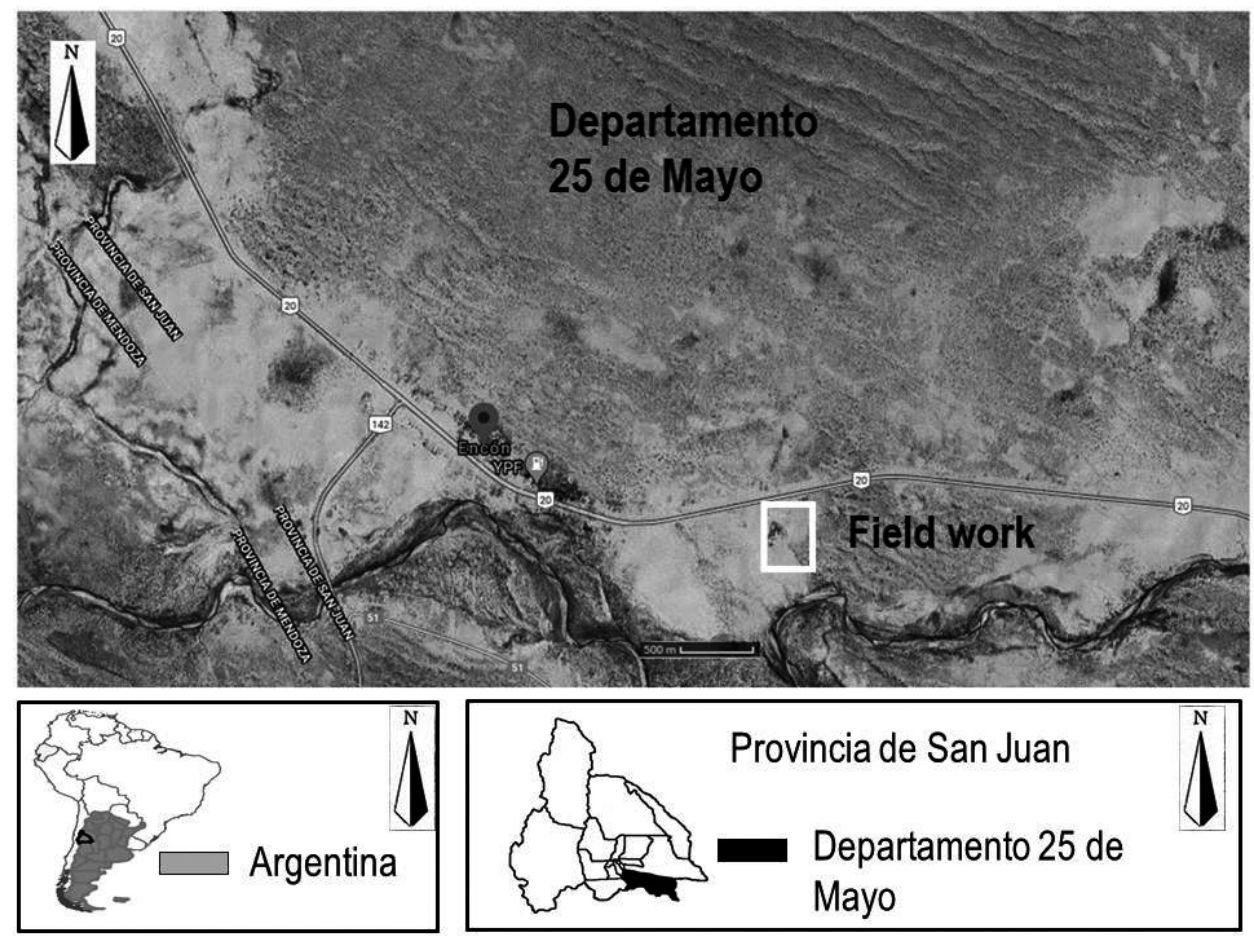

Fig. 1. Province of San Juan, Argentina, showing the location of the present study 

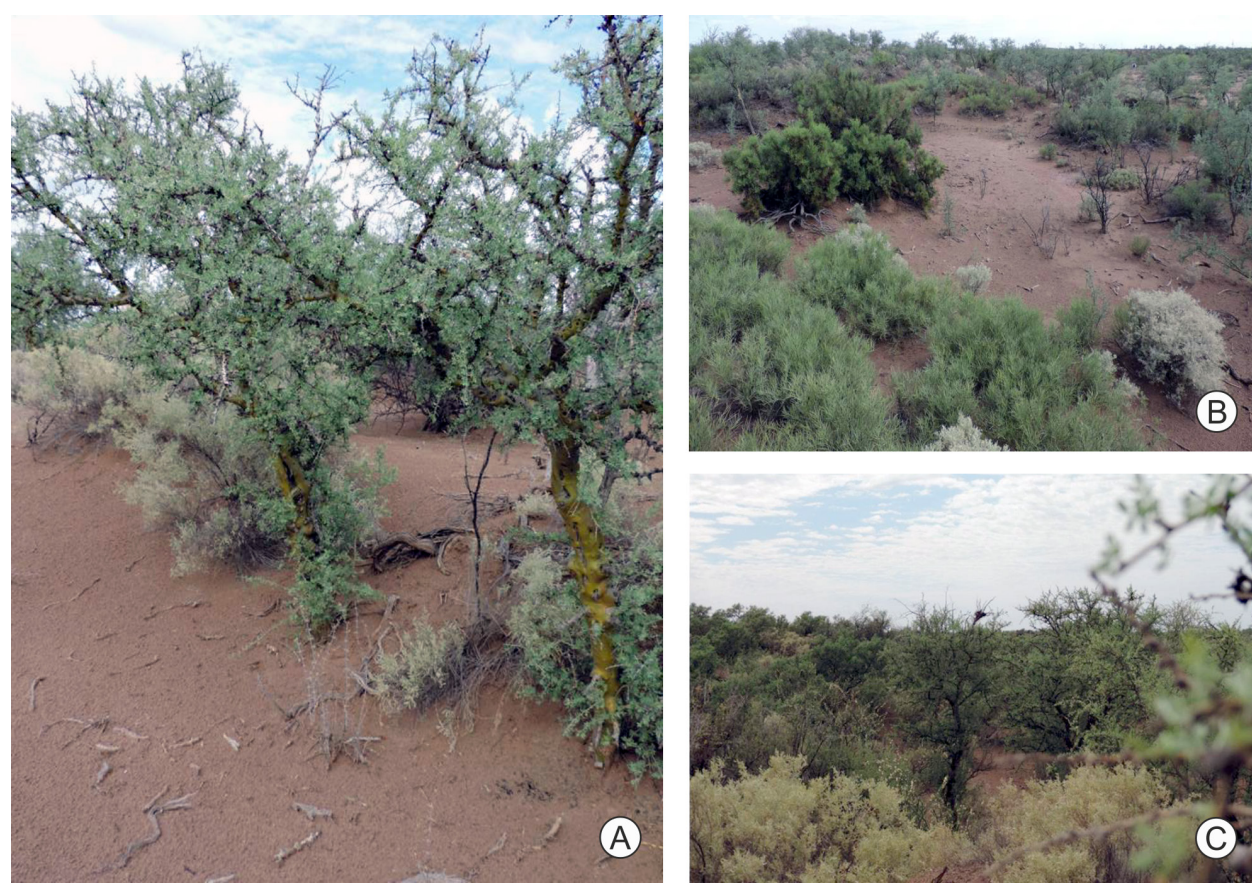

Fig. 2. Environments where the samplings were performed. Capture locations of L. darwinii, L. riojanus and A. longicauda. Town of the Encón, Department of 25 de Mayo (A, B, C)
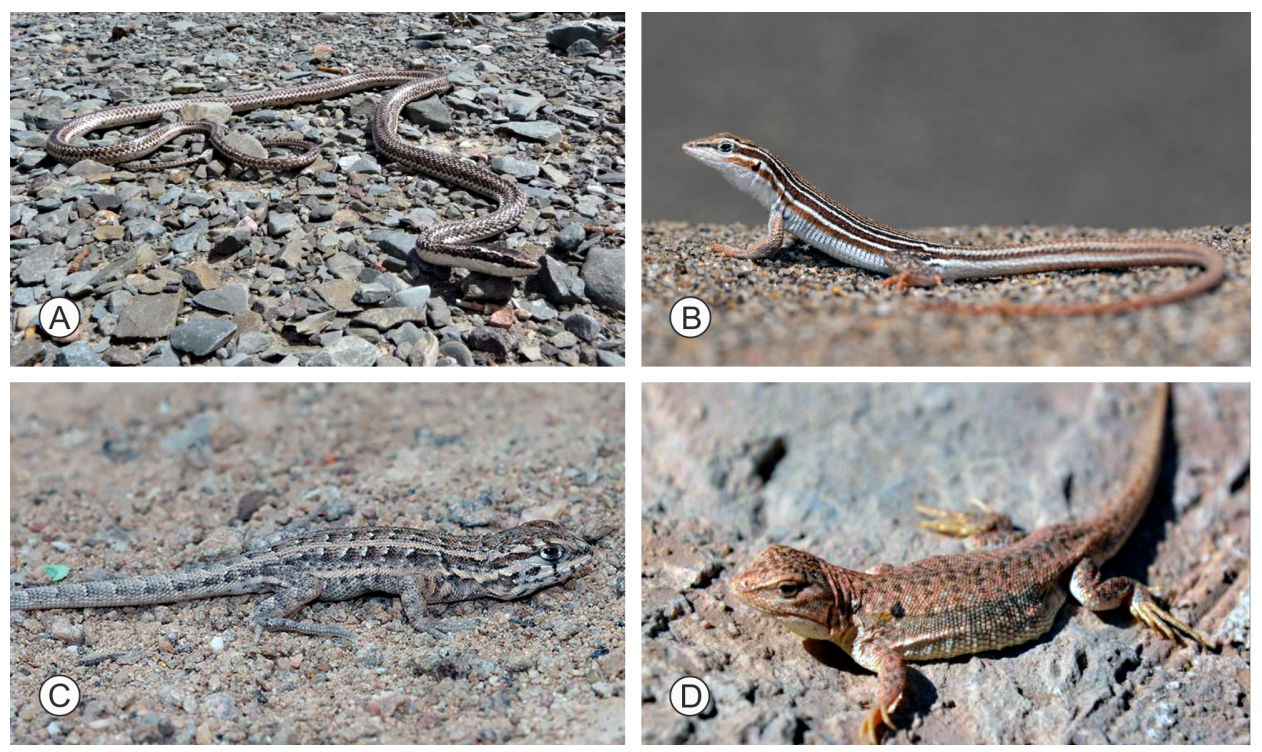

Fig. 3. Studied hosts. A = Philodryas trilineata, $\mathrm{B}=$ Aurivela longicauda (photo: Ignacio Hernandez), $\mathrm{C}=$ Liolaemus darwinii (photo: Claudio Mendez), $\mathrm{D}=$ Liolaemus riojanus 


\section{RESULTS}

Three taxa of nematode parasites were identified: Physaloptera sp. (larvae), Physaloptera retusa (adults) (Physalopteridae) and Parapharyngodon riojensis (adults) (Pharyngodonidae). Eight specimens of $A$. longicauda (4 males, 4 females) were examined, and 36 nematodes corresponding to two taxa were isolated in their stomachs: Physaloptera retusa (14 females, 2 males) and Parapharyngodon riojensis ( 15 females, 5 males). Fourty specimens of $L$. darwinii were examined (24 females, 16 males), and 16 nematodes were registered, corresponding to larval stages of Physaloptera sp. Only two specimens of L. riojanus and one of $P$. trilineata were analized, finding larvae of Physaloptera sp. (Table 2).

\section{DISCUSSION}

In the present study, Physaloptera (larvae and adults) infecting L. riojanus, L. darwinii, P. trilineata and A. longicauda from the Monte desert, represent new host records.

Currently in Argentina, 14 reptile species infected by Physaloptera spp. have been reported: L. quilmes, L. ornatus, L. alticolor, L. koslowskyi, L. neuquensis, L. olongasta, Salvator rufescens, A. tergolaevigata, H. underwoodi, T. etheridgei, L. catamarcensis, L. belli, P. scapulatus and X. merremi (Ramallo \& Díaz 1998, O'Grady \& Dearing 2006, Goldberg et al. 2004, Cruz et al. 1998, Lamas et al. 2016, Castillo et al. 2019a,b,c,d, Gallardo et al. 2019). Physaloptera sp. parasitizing the present hosts raises to 18 the number of reptile species infected by this genera of nematode in Argentina.

Table 2. Quantitative descriptors of nematodes infection in a sector from the Monte region, centralwestern Argentina. $\mathrm{P}=$ Prevalence, $\mathrm{MI}=$ Mean intensity; $\mathrm{MA}=$ Mean abundance; $\mathrm{N}=$ examined host; $\mathrm{np}=$ total number of parasite. Mean values are followed by \pm 1 standard deviation (range).

\begin{tabular}{|c|c|c|c|c|c|c|c|}
\hline Host & $\mathrm{N}$ & Nematode & $\mathrm{np}$ & $\mathrm{P} \%$ & MI & MA & $\begin{array}{l}\text { Site of } \\
\text { infection }\end{array}$ \\
\hline \multirow[t]{2}{*}{$\begin{array}{l}\text { Aurivela } \\
\text { longicauda }\end{array}$} & 4 & $\begin{array}{c}\text { Physaloptera retusa } \\
\text { (adults) }\end{array}$ & 16 & 50 & $4 \pm 3.5(1-8)$ & $2 \pm 3.16$ & Stomach \\
\hline & & $\begin{array}{l}\text { Parapharyngodon } \\
\text { riojensis (adult) }\end{array}$ & 20 & 12.5 & $20 \pm 0$ & $2.5 \pm 7.07$ & Stomach ${ }^{*}$ \\
\hline $\begin{array}{l}\text { Liolaemus } \\
\text { darwinii }\end{array}$ & 40 & $\begin{array}{l}\text { Physaloptera sp. } \\
\text { (larvae) }\end{array}$ & 16 & 30 & $1.3 \pm 0.4(1-2)$ & $0.4 \pm 0.6$ & Stomach \\
\hline $\begin{array}{l}\text { Liolaemus } \\
\text { riojanus }\end{array}$ & 2 & $\begin{array}{c}\text { Physaloptera sp. } \\
\text { (larvae) }\end{array}$ & 1 & 50 & 1 & $0.5 \pm 0.7(0-1)$ & Intestine \\
\hline $\begin{array}{l}\text { Philodryas } \\
\text { trilineata }\end{array}$ & 1 & $\begin{array}{c}\text { Physaloptera sp. } \\
\text { (larvae) }\end{array}$ & 1 & 100 & 1 & 1 & Stomach \\
\hline
\end{tabular}

* These nematodes migrate to the stomach due to the fixation method. Probable location = large intestine 
Physaloptera has heteroxenous life cycle and its intermediate hosts are mainly from the Orders Ortophtera and Coleoptera (ANDERson et al. 2000). This genus currently includes 105 species which are parasites inreptiles, amphibians, birds and mammals (Pereira et al. 2012, 2014). In the Neotropics, eight species that parasitize the stomach of reptiles are known: $P$. bonnei Ortlepp, 1922, P. liophis Vicente et Santos, 1974, P. lutzi Cristofaro, Guimaraes et Rodrigues, 1976, P. monodens Molin, 1860, P. obtusissima Molin, 1860, P. retusa Rudolphi, 1819, P. tupinambae Pereira, Alves, Rocha, Lima et Luque, 2012 and P. bainae Pereira, Alves, Rocha, Lima et Luque, 2014 (Castillo et al. 2019c).

Reptiles have been mentioned as paratenic hosts (WIDMER 1970). Liolaemus darwinii would have a role as a paratenic host in the life cycle of Physaloptera sp. A possible definitive host, Salvator rufescens, in which adult stages of Physaloptera were recorded (CAstillo et al. 2019b). This was captured in the same place as L. darwinii. Aurivela longicauda would have a definitive host role, probably by feeding on other lizards. We have records that $A$. longicauda has a tendency to feed on other lizards (Blanco et al. 2012).

Parapharyngodon riojensis as a parasite of $A$. longicauda from the Monte desert, also represents a new host record. It is a generalist nematode, and in Argentina it parasitizes Liolaemus spp., Phymaturus spp. and Tropidurus spp. (Ramallo et al. 2002, Goldberg et al. 2004, Castillo et al. 2017, Ramallo et al. 2017, Castillo et al. 2018, Castillo et al. 2019d). Parapharyngodon riojensis is very common in reptiles of the San Juan province (CAstillo \& Acosta 2019, Castillo et al. 2019d).

According to our bibliographic review, in Argentina there are currently 15 lizard species parasitized by Parapharyngodon spp. (CRUz et al. 1998, RAmallo et al. 2002b, Goldberg et al. 2004, Lamas \& Zaracho 2006, Ramallo et al. 2016, Ramallo et al. 2017, CAstillo et al. 2017, CAstillo et al. 2018, CAstillo et al. 2019e, CAstillo et al. 2019c, CAstillo \& Acosta 2019).

The probability that an uninfected host will become infected would depend on the frequency of movement (Getz \& Pickering 1993). Aurivela longicauda is a more agile, faster and more moving species than $L$. darwinii. Infection is more likely in $A$. longicauda. In addition, the relationship between lizard SVL (snout vent length) and the intensity of nematode infection suggest that body size is an important determinant of the infection rate (RibAs et al. 1995, Anjos et al. 2012). The larger digestive tract of the larger lizards (A. longicauda), provides more microhabitats suitable for nematode settlement compared to the relatively smaller one of $L$. darwinii.

Considering the large number of lizard species registered in Argentina, current knowledge on their parasitic nematodes is incomplete and fragmented. The present report expands the number of host species and the geographi- 
cal distribution of $P$. riojensis and Physaloptera spp. representing a valuable contribution to parasitological knowledge and adding to knowledge of this species in the Monte desert of Argentina.

We emphasize that the results obtained with respect to the parasites of $A$. longicauda are similar to those of other phylogenetically related species. Parapharyngodon spp. and Physaloptera spp. was reported in lizards of the family Teiidae (Ávila \& Silva 2010, Gallardo et al. 2019, Vieira et al. 2019).

Acknowledgement - We thank the Sub-Secretary of the Environment for the permits granted (№ 1300-3097-16), and the rangers (Mariano Hidalgo, Jorge Cayuela, Jesús Quiroga and José Castro) for their help in field samplings. Sofía Nanni assisted us in drafting the English version. We thank two anonymous reviewers for improving the manuscript.

The authors declare no competing interests.

\section{REFERENCES}

Abdala, C. S., Acosta, J. C., Acosta, J. L., Álvarez, B. B., Arias, F., Avila, L., Blanco, M. G., Bonino, M. J., Boretto, M., Brancatelli, G., Breitman, M. F., Cabrera, M., CaIro, R. S., Corbalán, V., Hernando, A., Ibarguengoytía, N. R., Kacoliris, F., Laspiur, A., Montero, R., Morando, M., Pelegrín, N., Pérez, C. H. F., Quinteros, A., Semhan, S. R. V., Tedesco, M. E., Vega, L. \& Zalba, S. M. (2012): Categorización del estado de conservación de las lagartijas y anfisbenas de la República Argentina. - Cuadernos de Herpetología 26: 215-248.

Ано, J. М. (1990): Helminth communities of amphibian and reptiles: comparative approaches to understanding patterns and processes. Pp. 157-195. In: EscH, G. W., Bush, A. O. \& Ано, J. M. (eds): Parasite communities: Patterns and processes. - Chapman and Hall, NY. https://doi.org/10.1007/978-94-009-0837-6_7

Anderson, R. C. (2000): Nematodes parasites of vertebrates: Their development and transmission. 2nd ed. - CABI Publishing, Wallingford, UK, 650 pp.

Anjos, L. A., Rocha, C. F. D., Vrcibradic, D. \& Vicente, J. J. (2005): Helminths of the exotic lizard Hemidactylus mabouia from a rock outcrop area in southeastern Brazil. - Journal of Helminthology 79(4): 307-313. https://doi.org/10.1079/JOH2005288

Anjos, L. A., Ávila, R. W., Ribeiro, S. C., Almeida, W. O. \& da Silva, R. J. (2012): Gastrointestinal nematodes of the lizard Tropidurus hispidus (Squamata: Tropiduridae) from a semi-arid region of north-eastern Brazil. - Journal of Helminthology 87(4): 443-449. https://doi.org/10.1017/S0022149X12000491

Ávila, R. W. \& Silva, R. J. (2010): Checklist of helminths from lizards and amphisbaenians (Reptilia, Squamata) of South America. - Journal of Venomous Animals and Toxins including Tropical Diseases 16: 543-572. https://doi.org/10.1590/S1678-91992010000400005

Blanco, M. G., Acosta, J. C., Piaggio, L., Nieva, R., Victorica, A. \& Castillo, G. (2012): Saurofagia y canibalismo en dos especies de lagartos del centro-oeste de Argentina. - Cuadernos de herpetología 26: 91-93.

Brito, S. V., Corso, G., Almeida, A. M., Ferreira, F. S., Almeida, W. O., Anjos, L. A., MesQuita, D. O. \& VAsconcellos, A. (2014): Phylogeny and micro-habitats utilized by 
lizards determine the composition of their endoparasites in these miarid Caatinga of Northeast Brazil. - Parasitology Research 113: 3963-3972. https://doi.org/10.1007/ s00436-014-4061-z

Bush, A. O., Lafferty, K. D., Lotz, J. M. \& Shostak, A. W. (1997): Parasitology meets ecology on its own terms. - Journal of Parasitology 83: 575-583. https://doi.org/10.2307/3284227

Cabrera, A. L. (1976): Enciclopedia Argentina de agricultura y jardinería: regiones fitogeográficas Argentinas. - Acme, Buenos Aires, 85 pp.

Castillo, G. N., Ramallo, G. \& Acosta, J. C. (2017): Liolaemus ruibali. Endoparasites. Herpetological Review 48: 651-652.

Castillo, G., Acosta, J. C., Ramallo, G. \& Pizarro, J. (2018): Pattern of infection with Parapharyngodon riojensis Ramallo, Bursey, Goldberg 2002 (Nematoda: Pharyngodonidae) in the lizard Phymaturus extrilidus from Puna region, Argentina. - Annals of Parasitology 64(2): 83-88.

Castillo, G. N. \& Acosta, J. C. (2019): Parasitism in two species of lizards of the genus Liolaemus (Wiegmann, 1834) from the puna Argentina. - Neotropical Helminthology 13: 89-95.

Castillo, G. N., González- Rivas, C. J. \& Acosta, J. C. (2019a): Liolaemus olongasta (Chelco Lizard). Endoparasites. - Herpetological Review 50: 578-579.

Castillo, G. N., González- Rivas, C. J. \& Acosta, J. C. (2019b): Nematode parasites in the lizards Salvator rufescens, Teiusteyou (Teiidae) and Homonota underwoodi (Phyllodactylidae) from the Monte Region in Central-Western Argentina. - North-Western Journal of Zoology 15: 192-195.

Castillo, G. N., Acosta, J. C. \& Acosta, R. (2019c): Liolaemus fitzgeraldi. Endoparasites. Herpetological Review 50: 578-579.

Castillo G. N., Acosta, J. C. \& Blanco, G. M. (2019d): Trophic analysis and parasitological aspects of Liolaemus parvus (Iguania: Liolaemidae) in the Central Andes of Argentina. - Turkish Journal of Zoology 43: 277-286. https://doi.org/10.3906/zoo-1812-33

Cruz, F. B., Silva, S. \& Scrocchi, G. J. (1998): Ecology of the lizard Tropidurus etheridgei (Squamata: Tropiduridae) from the dry Chaco of Salta, Argentina. - Herpetological Natural History 6: 23-31. https://doi.org/10.2307/1565679

Gallardo, G. A., Tulli, M. J. \& Scrocchi, G. J. (2019): Dimorfismo sexual y ecología trófica de Aurivelatergo laevigata (Squamata, Teiidae). - Revista del Museo Argentino de Ciencias Naturales nueva serie 21(1): 45-50. https://doi.org/10.22179/REVMACN.21.606

Getz, W. M. \& Pickering, J. (1983): Epidemic models thresholds and population regulation. - American Naturalist 121: 892-898. https://doi.org/10.1086/284112

Giraudo, A. R., Arzamendia, V., Bellini, G., Bessa, C. A., Calamante, C. C., Cardozo, G., Chiaraviglio, M., Costanzo, M. B., Etchepare, E. G., Cola, V. \& Di Pietro, D. O. (2012): Categorización del estado de conservación de las Serpientes de la República Argentina. - Cuadernos de herpetología 26: 303-374.

Goldberg, S. R., Bursey, C. R. \& Morando, M. (2004): Metazoan endoparasites of 12 species of lizards from Argentina. - Comparative Parasitology 71: 208-214. https://doi. org/10.1654/4089

Karlin, U. O., Karlin, M. S., Zapata, R. M., Coirini, R. O., Contreras, A. M. \& Carnero, M. (2017): La provincia fitogeográfica del Monte: límites territoriales y su representación. - Multequina 26: 63-75.

Lamas, M. \& Zaracho, V. (2006): Tropidurus torquatus (Brown Lizard). Endoparasites. Herpetological Review 37: 474-475. 
Lamas, M. F., Céspedez, J. A., Ruiz-García, J. A. (2016): Primer registro de nematodes parásitos para la culebra Xenodon merremi (Squamata, Dipsadidae) en Argentina. - Facena 32: 59-67.

Márquez, J., Martínez Carretero, E. \& Dalmasso, A. (2016): Provincias fitogeográficas de la Provincia de San Juan. Pp. 187-197. In: Martínez Carretero, E. \& Garcia A. (eds): San Juan Ambiental. 1o edición. - Editorial INCA, Mendoza.

O'Grady, S. P. \& Dearing, M. D. (2006): Isotopic insight into host-endosymbiont relationships in Liolaemidae lizards. - Oecologia 150: 355-361. https://doi.org/10.1007/s00442006-0487-z

Pereira, F. B., Sousa, B. M. \& de Souza Lima, S. (2012): Helminth community structure of Tropidurus torquatus (Squamata: Tropiduridae) in a rocky outcrop area of Minas Gerais state, southeastern Brazil. - Journal of Parasitology 98: 6-10. https://doi. org/10.1645/GE-2689.1

Pereira, F. B., Alves, P. V., Rocha, B. M., de Souza Lima, S. \& Luque, J. L. (2014): Physaloptera bainae n. sp. (Nematoda: Physalopteridae) parasitic in Salvator merianae (Squamata: Teiidae), with a key to Physaloptera species parasitizing reptiles from Brazil. - Journal of Parasitology 100: 221-228. https://doi.org/10.1645/13-281.1

Ramallo, G. R. \& Díaz, F. (1998): Physaloptera lutzi (Nematoda, Physalopteridae) parasite de Liolaemus (Iguania, Tropiduridae) del noroeste Argentino. - Boletín Chileno de Parasitología 53: 19-22.

Ramallo, G., Bursey, C., Castillo, G. \& Acosta, J. C. (2016): New species of Parapharyngodon (Nematoda: Pharyngodonidae) in Phymaturus spp. (Iguania: Liolaemidae) from Argentina. - Acta Parasitologica 61: 461-465. https://doi.org/10.1515/ap-2016-0062

Ramallo, G., Bursey, C. H., Goldberg, S., Castillo, G. \& Acosta, J. C. (2017): Phymaturus extrilidus (Argentine Lizard). Endoparasites. - Herpetological Review 48: 198.

Ramallo, G., Bursey, C. R. \& Goldberg, S. R. (2002): Parapharyngodon riojensis n. sp. (Nematoda: Pharyngodonidae) from the lizard Phymaturus punae (Squamata: Iguania: Liolaemidae) from northwestern Argentina. - Journal of Parasitology 88: 979-982. https://doi.org/10.2307/3285541

Ribas, S. C., Rocha, C. F. D., Teixeira-Filho, P. F. \& Vicente, J. J. (1995): Helminths (Nematoda) of the lizard Cnemidophorus ocellifer (Sauria: Teiidae): Assessing the effect of rainfall, body size and sex in the nematode infection rates. - Ciencia e Cultura 47: 88-91.

Van Sluys, M., Rocha, C. F. D. \& Ribas, S. C. (1994): Nematodes infecting the lizard Tropidurus itambere in southeastern Brazil. - Amphibia-Reptilia 15(4): 405-408. https://doi. org/10.1163/156853894X00443

Vieira, F. M., de Souza, T. T., Novelli, I. A., Lima, S. S., Muniz-Pereira, L. C. \& de Sousa, B. M. (2019): Nematode parasites of lizards (Squamata, Sauria) from the Cerrado biome in the State of Minas Gerais, Brazil. - Herpetology Notes 12: 855-863.

Vrcibradic, D., Rocha, C. F. D., Ribas, S. C. \& Vicente, J. J. (1999): Nematodes infecting the skink Mabuya frenata in Valinhos, São Paulo state, southeastern Brazil. - AmphibiaReptilia 20: 333-339. https://doi.org/10.1163/156853899X00367

Widmer, E. A. (1970): Development of third-stage Physaloptera larvae from Crotalus viridis Rafinesque, 1818 in cats with notes on pathology of the larvae in the reptile (Nematoda, Spiruroidea). - Journal of Wildife Diseases 6: 89-93. https://doi.org/10.7589/00903558-6.2.89

Received April 7, 2020, accepted August 7, 2020, published November 13, 2020 


\title{
Amphistomes of the World A check-list of the amphistomes of vertebrates
}

\author{
O. Sey
}

The amphistomes are one of the rare groups of digenetic trematodes which have a broad spectra of the definitive hosts together with a wide geographical distribution, forming a continuous evolutional lineage from fishes to mammals. At the same time, some species of them are causative agents of devastating disease of domestic and wild animals, mainly ruminants. Therefore, amphistomes may have professional and practical interests for research and thus a great number of information has been accumulated on their classification and biology. The intention of this check-list is to bring together a comprehensive list of the amphistomes, presently known and sources of references of their hosts and geographic distribution (87 pages). This list consists of three main parts. In the first "Parasite/host check-list" (137 pages), parasites were listed under their scientific names, followed by the synonyms, then the name of the authorship as well as the name of the countries from which they were reported. In the second "General host/parasites check-list" (31 pages), host were listed systematically under their scientific names from fishes to mammals, followed by amphistomes described in them in alphabetical order. In the third "Host/parasites check-list by countries" (63 pages), countries were listed alphabetically, hosts systematically and their parasites alphabetically. When it seemed to be necessary some comments were given and they are found in Chapter 7 "Notes" (5 pages). Three indexes (parasite, host and countries) are added to the list (29 pages).

Published in 2001. Hard bound, 368 pages. Price: 30 euro plus p. and p.

ISBN 9636418659

\section{Orders should be sent to}

The Library, Hungarian Natural History Museum

H-1088 Budapest, Baross u. 13, Hungary

Fax: (36-1) 3171669 